\title{
Effect of Simulated Microgravity on Metabolite Concentrations in the Muscles and Liver of Developing Japanese Quail Chicks
}

\author{
P. ŠKROBÁNEK, M. BARANOVSKÁ, B. ŠÁRNIKOVÁ, M. JURÁNI \\ Institute of Animal Biochemistry and Genetics, Slovak Academy of Sciences, Ivanka pri Dunaji, \\ Slovak Republic \\ Received March 23, 2006 \\ Accepted November 29, 2006
}

\begin{abstract}
Škrobánek, P., M. Baranovská, B. Šárniková, M. Juráni: Effect of Simulated Microgravity on Metabolite Concentrations in the Muscles and Liver of Developing Japanese Quail Chicks. Acta Vet Brno 2007, 76: 9-16.

Hypodynamy is the most frequently used ground-based model to study the negative consequences of microgravity on an animal organism. The objective of the current experiment was to examine the influence of hypodynamy on the growth and development of the breast muscle, thigh muscles and liver in female Japanese quail chicks from 3 to $56 \mathrm{~d}$ of age. Samples of muscles and liver were obtained at 1, 14, 28, 42 and $56 \mathrm{~d}$; the variables studied were: weight $(\mathrm{g})$, relative weight $(\%)$, dry matter $(\mathrm{mg} / \mathrm{g})$ and content of total proteins, total lipids and glycogen (mg/g).

The actual weight of breast muscle, thigh muscles and liver gradually increased with age of quail in both groups. However, the experimental birds exposed to hypodynamy showed a reduction in growth relative to age-matched control. At the end of testing, the body weight of the hypodynamy group was significantly lesser than that of control $(P<0.05)$. The control birds had also significantly heavier breast muscle than those of experimental group. Similarly, the dry matter and total lipid content in both muscles and liver of control group was significantly increased $(P<0.05)$. On the contrary, the differences in the content of total protein and glycogen in muscles and liver of both groups were not significant at the end of experiment.

These results provide further evidence that, although hypodynamy affects the examined variables of selected skeletal muscles and liver, the female Japanese quail is able to develop under conditions of simulated weightlessness.
\end{abstract}

Hypodynamy, muscle, liver, proteins, lipids, glycogen

The effect of microgravity on avian embryogenesis has been studied by several teams of scientists (Hullinger 1993; Orban et al. 1999). It has been shown that embryogenesis of Japanese quail can be successfully performed in the weightless environment. Upon hatching, the birds appeared morphologically normal (Dadasheva et al. 2001; Guryeva et al. 1993). However, only two space flight experiments have examined the effects of altered gravity on quail post-hatch development. In these experiments conducted on board MIR space station, Japanese quail chicks were exposed to microgravity for four days (B od'a et al. 1992; S abo et al. 2001). How microgravity may influence their further development during the different ontogeny phases is unknown. A partial answer may be provided by the ground-based animal models of simulated microgravity (hypodynamy). The first studies to examine the effect of hypodynamy were carried out on the adult Japanese quail (Juráni et al. 1983), followed by a similar experiment aimed at post-hatching development of Japanese quail chicks (Šk robánek et al. 2001).

The objective of this study was to investigate the influence of simulated microgravity (hypodynamy) on total protein, total lipid and glycogen contents in the breast muscle, thigh muscles and liver of female Japanese quail chicks reared under hypodynamy from d 3 posthatch to $56 \mathrm{~d}$ of age.

Address for correspondence:

Ing. Peter Škrobánek, CSc.

Institute of Animal Biochemistry and Genetics

Slovak Academy of Sciences

Moyzesova 61, 90028 Ivanka pri Dunaji, Slovak Republic
Phone: +4210245943881

Fax: + 4210245943932

E-mail: peter.skrobanek@savba.sk

http://www.vfu.cz/acta-vet/actavet.htm 


\section{Materials and Methods}

One hundred and six one-day-old female Japanese quail chicks (Laying Line 01 Ivanka pri Dunaji) were individually weighed (mean body weight $7.74 \pm 0.58 \mathrm{~g}$ ) and assigned at random into two groups, experimental $(\mathrm{n}=68$; exposed to hypodynamy) and control $(\mathrm{n}=38)$. On the day of hatch, 8 birds per treatment were killed to obtain the initial values of biochemical indicators in muscles and liver. On the third day after hatching, remaining sixty chicks from the experimental group were exposed to hypodynamy (Šk robánek et al. 2004). Hypodynamy is a simulation of weightlessness where quail is placed in individual sling suspended by a flexible metal device such that its legs cannot touch the floor. The size of the sling was enlarged at 7, 14, 21, 28 and 35 days of age (from $4 \times 3 \mathrm{~cm}$ to $5 \times 4 \mathrm{~cm}$ to $6 \times 5 \mathrm{~cm}$ to $7 \times 6 \mathrm{~cm}$ and $8 \times 7 \mathrm{~cm}$ ) to accommodate the growth of the quail. At the same time, thirty quail chicks (control group) were placed in a rearing box $(0.6 \times 0.6 \times 0.3 \mathrm{~m})$. The birds of both groups were kept under these conditions until $56 \mathrm{~d}$ of age in windowless poultry room with controlled ventilation and heating by infrared lamps. The temperature was gradually reduced from $35-36^{\circ} \mathrm{C}$ for the first few days after hatching to about $20^{\circ} \mathrm{C}$ at $4 \mathrm{wk}$ of age, remained on this level until the end of the experiment. A commercial starter mash HYD- 13 and water were available ad libitum. The diet contained $260 \mathrm{~g} / \mathrm{kg}$ protein and $11.5 \mathrm{MJ}$ metabolisable energy $/ \mathrm{kg}$. Lighting in the rearing room was continuous. The care and use of animals were in accordance with laws and regulations of the Slovak Republic and were approved by the Ethical Committee of the Institute of Animal Biochemistry and Genetics of Ivanka pri Dunaji.

Individual body weight of quail was recorded on days 1, 14, 28, 42 and 56 of age, before the aliquot number of test and control birds was euthanized by cervical dislocation. Breast muscle ( $m$. supracoracoides), thigh muscles ( $m$. sartorius, $m$. tensor fasciae latae, $m$. biceps femoris, $m$. semitendinosus, $m$. semimembranosus) and liver were quickly dissected and weighed to the nearest $0.001 \mathrm{~g}$, and sectioned for determination of dry matter (mg/g), total protein $(\mathrm{mg} / \mathrm{g})$, total lipid $(\mathrm{mg} / \mathrm{g}$ ) and glycogen $(\mathrm{mg} / \mathrm{g}$ wet tissue). The samples of muscles and liver were then immediately stored at $-20^{\circ} \mathrm{C}$ until analysis, except those used for determination of dry matter. These samples were placed in an oven at $105^{\circ} \mathrm{C}$ for 4 hours and their dry weight was measured subsequently. Total proteins were determined by the method of Lowry et al. (1951). Total lipids were measured by colourimetric kit assay (BIOLA-TEST, PLIVA - Lachema a.s., Czech Republic). Glycogen was assayed by the technique of Dreiling et al. (1987). The results were expressed as milligrams of total protein, total lipid and glycogen per gram wet weight of tissue (muscle, liver). Data from both groups were analyzed by two-way analysis of variance (ANOVA) with age and treatment as factors. In each analysis, significant differences among means were detected using Tukey multiple comparison test. In all cases the level of significance was set at $P<0.05$. All values are presented as mean $\pm \mathrm{SEM}$.

\section{Results}

There was a significant effect of treatment and age, respectively, on the majority of studied biochemical indicators $(P<0.001)$. An ANOVA also revealed significant interactions between the treatment and age of Japanese quail females $(P<0.001)$.

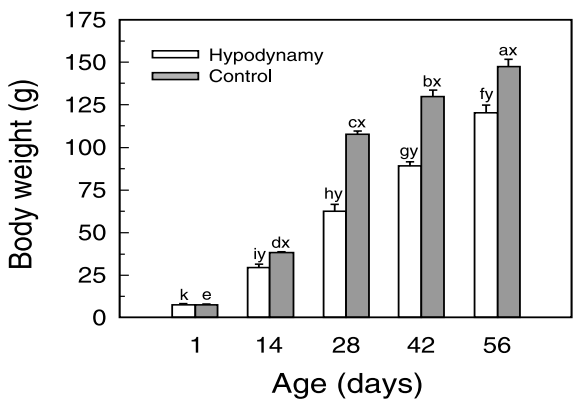

Fig. 1. Mean body weight of female Japanese quail developing in simulated microgravity.

Values are means + - SEM, $\mathrm{n}=8$.

$(\mathrm{a}, \mathrm{b}, \mathrm{c}, \mathrm{d}, \mathrm{e})$ Means of control with different superscripts are significantly different $(P<0.05)$.

$(\mathrm{f}, \mathrm{g}, \mathrm{h}, \mathrm{i}, \mathrm{k})$ Means of hypodynamy with different superscripts are significantly different $(P<0.05)$.

$\left({ }^{\mathrm{x}, \mathrm{y}}\right)$ Means of control and hypodynamy with different superscripts are significantly different $(P<0.05)$.

The mean body weight of female Japanese quail developing in hypodynamy is shown in Fig. 1. The body weight in both groups increased gradually with growth. However, the body weight of experimental quail was markedly lower (about 18\%) than that of the age-matched control at the end of experiment. Similarly, the mean actual wet weight of breast muscle of 

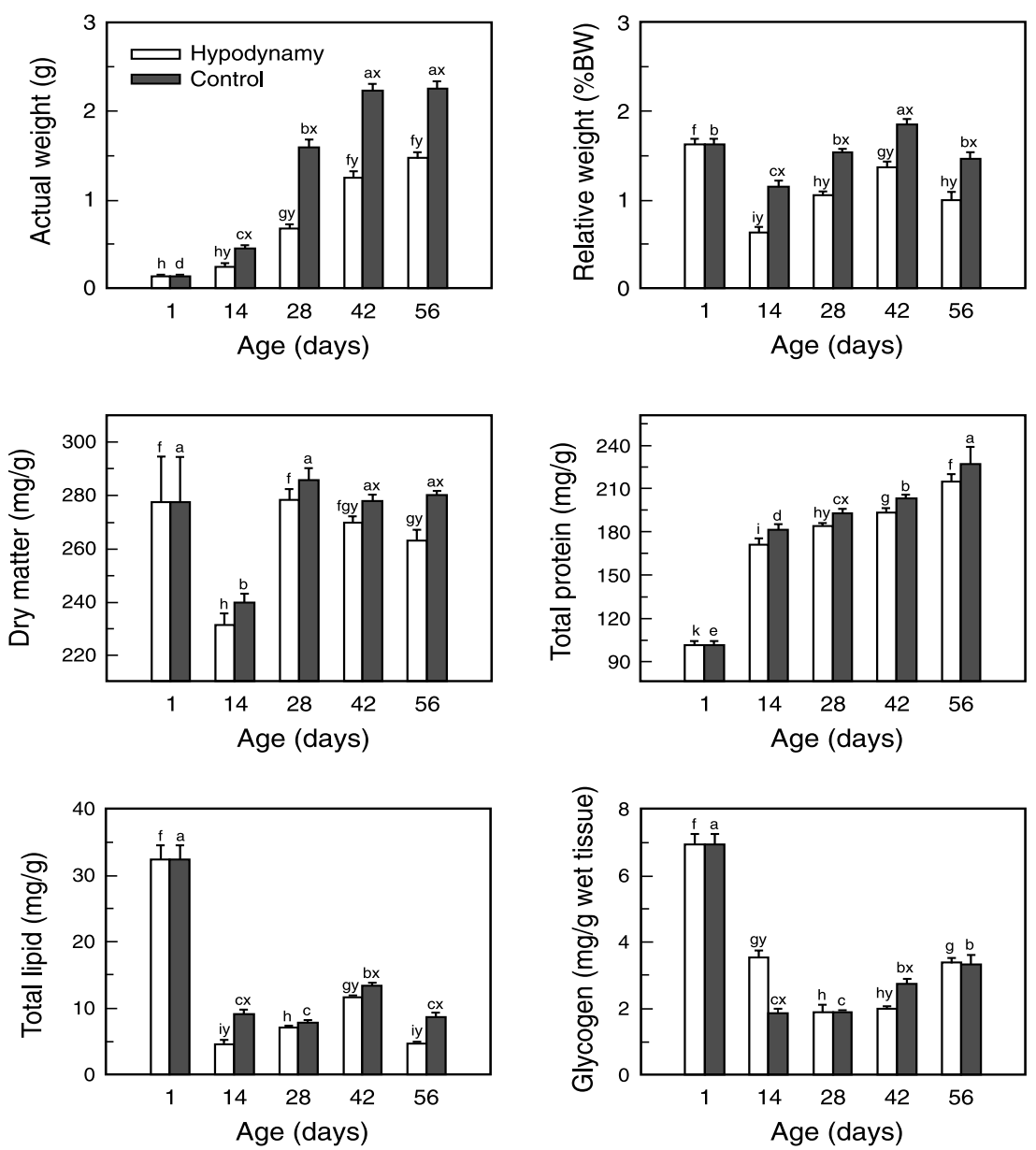

Fig. 2. Actual and relative weight (per cent of body weight - \%BW), dry matter and content of total protein, total lipid and glycogen in breast muscle of female Japanese quail developing in simulated microgravity. Values are means $+/$ - SEM, $\mathrm{n}=8$.

$(\mathrm{a}, \mathrm{b}, \mathrm{c}, \mathrm{d}, \mathrm{e})$ Means of control with different superscripts are significantly different $(P<0.05)$.

$(\mathrm{f}, \mathrm{g}, \mathrm{h}, \mathrm{i}, \mathrm{k})$ Means of hypodynamy with different superscripts are significantly different $(P<0.05)$.

$(\mathrm{x}, \mathrm{y})$ Means of control and hypodynamy with different superscripts are significantly different $(P<0.05)$.

hypodynamy group, as well as control, increased significantly from d 14 to 56 of age (Fig. 2). However, the actual weight of breast muscle in the quail exposed to hypodynamy was significantly reduced. The actual weight of breast muscle of experimental quail on d 56 of age was about $35 \%$ less than that of the control. The relative weight of breast muscle (expressed as a proportion of body weight) in the hypodynamy group was also significantly lower during the whole experimental period. The relative weight of breast muscles in both groups increased between d 14 and 42 of age. The dry matter of breast muscles of quail subjected to hypodynamy was also lower than that of control throughout the experiment. However, significant differences were only observed on d 42 and 56 of age. The total protein content in breast muscle of female Japanese quail gradually increased with age in both groups. The concentration of total proteins in the hypodynamy group was smaller compared 
with that of age-matched control. These differences were not significant except for $\mathrm{d} 28$. The total lipid content in quail breast muscle increased between days 14 to 42 of age; the differences between the experimental and control group were significant except for $\mathrm{d} 28$. The content of glycogen in breast muscle of female quail gradually increased between days 14 to 56 in both groups, with the exception of d 14 of age in birds reared under hypodynamy.
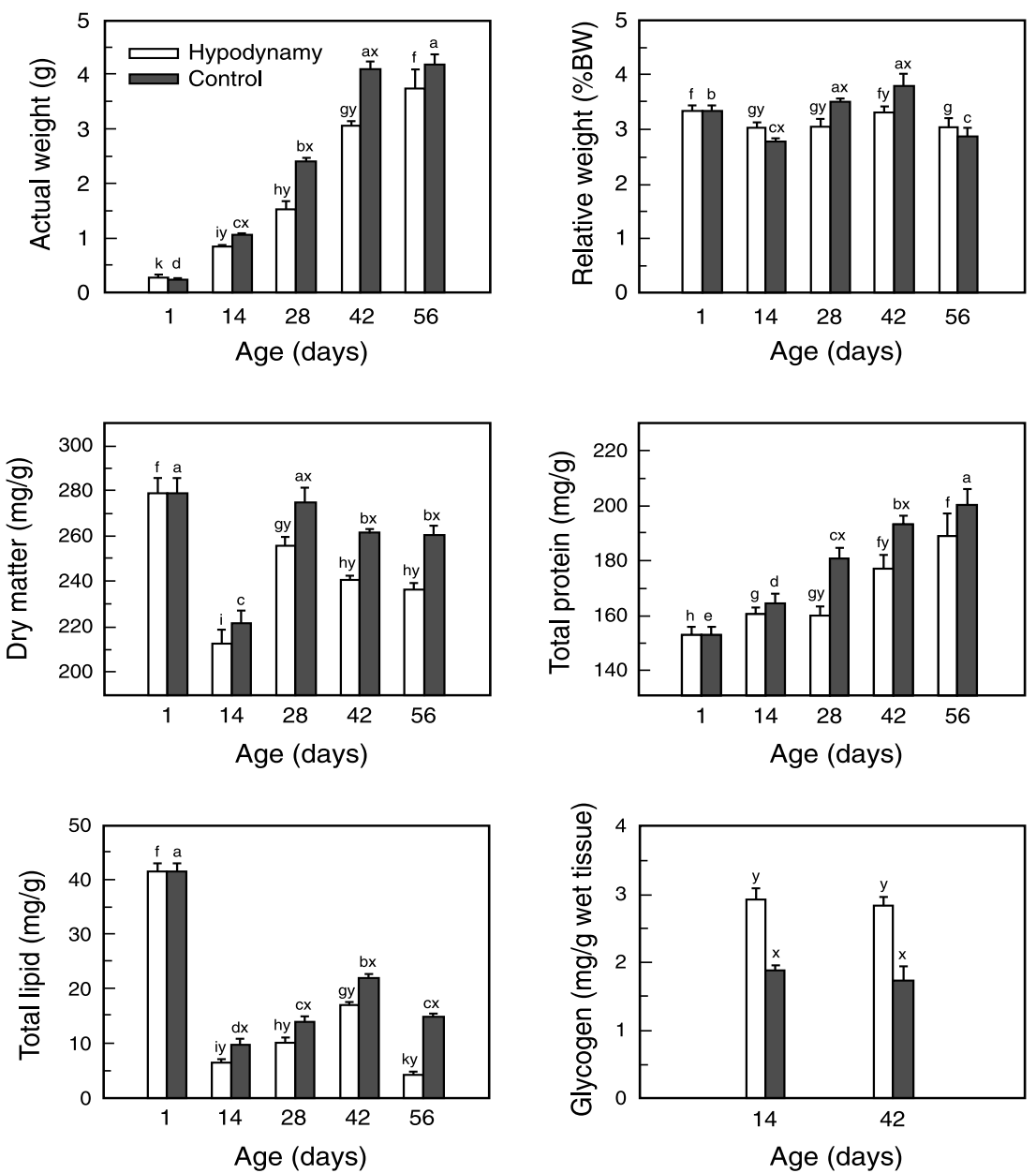

Fig. 3. Actual and relative weight (per cent of body weight - \%BW), dry matter and content of total protein, total lipid and glycogen in thigh muscles of female Japanese quail developing in simulated microgravity.

Values are means $+/$ - SEM, $\mathrm{n}=8$.

$(\mathrm{a}, \mathrm{b}, \mathrm{c}, \mathrm{d}, \mathrm{e})$ Means of control with different superscripts are significantly different $(P<0.05)$.

$(\mathrm{f}, \mathrm{g}, \mathrm{h}, \mathrm{i}, \mathrm{k})$ Means of hypodynamy with different superscripts are significantly different $(P<0.05)$.

$(\mathrm{x}, \mathrm{y})$ Means of control and hypodynamy with different superscripts are significantly different $(P<0.05)$.

The actual wet weight of thigh muscle increased significantly with age in both groups (Fig. 3). Nevertheless, the thigh muscle weight of hypodynamy quail was about $0.45 \mathrm{~g}$ lower than that of control at the end of experiment. This difference did not reach the level of statistical significance. The relative weight of thigh muscles increased between days 14 and 

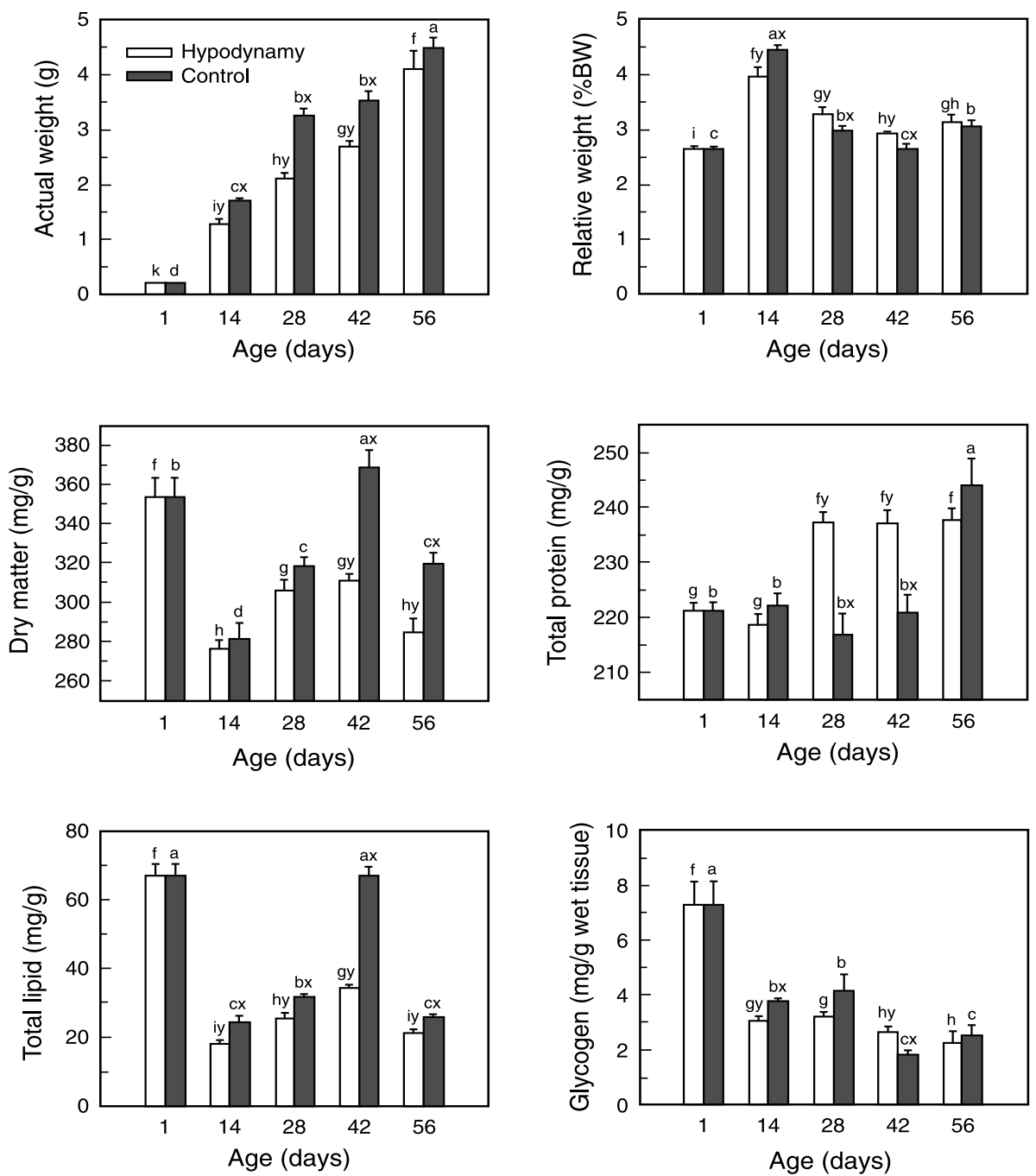

Fig. 4. Actual and relative weight (per cent of body weight - \%BW), dry matter and content of total protein, total lipid and glycogen in liver of female Japanese quail developing in simulated microgravity.

Values are means $+/$ - SEM, $\mathrm{n}=8$.

$(\mathrm{a}, \mathrm{b}, \mathrm{c}, \mathrm{d}, \mathrm{e})$ Means of control with different superscripts are significantly different $(P<0.05)$.

$(\mathrm{f}, \mathrm{g}, \mathrm{h}, \mathrm{i}, \mathrm{k})$ Means of hypodynamy with different superscripts are significantly different $(P<0.05)$.

$(\mathrm{x}, \mathrm{y})$ Means of control and hypodynamy with different superscripts are significantly different $(P<0.05)$.

42 and then declined on $\mathrm{d} 56$ of age. The relative thigh muscle weight of quail exposed to hypodynamy increased significantly on d 14. On days 28 and 42 of age, the relative thigh muscle weight of experimental group was significantly lower as compared to control. The dry matter of quail thigh muscles markedly increased between days 14 and 28 and then declined to the end of experiment. The differences between test and control group were significant on d 28 to 56 of age. Total protein in thigh muscles of female Japanese quail chicks gradually increased with age in both groups. However, the content of total protein in the hypodynamy quail was smaller than that of age-matched control. These differences were 
not significant with the exception of $\mathrm{d} 28$ and 42 . Total lipid in quail thigh muscles increased from d 14 to 42 of age; significant differences between test and control group were observed during the whole experiment. On the contrary, the glycogen content in thigh muscles of experimental quail was higher in comparison with control on d 14 and 42 of age.

Actual liver weight in both groups increased significantly until d 56 of age (Fig. 4). However, the liver weight of quail developing under hypodynamy was significantly lower than that of age-matched control already on $\mathrm{d} 14$. At the end of experiment, the mean liver weight of quail exposed to hypodynamy was non-significantly reduced by about $9 \%$. By contrast, relative liver weight in test and control group decreased between 14 and $42 \mathrm{~d}$ of age. The differences between hypodynamy and control group were significant. Dry matter of liver in the hypodynamy group, as well as control, increased between 14 and $42 \mathrm{~d}$ and decreased markedly at $56 \mathrm{~d}$ of age. There were significant differences between experimental and control group from 42 to $56 \mathrm{~d}$ of age. The content of total protein in the liver of female quail subjected to hypodynamy increased considerably at $28 \mathrm{~d}$ and it remained on this level up to the end of experiment. Total protein in the liver of control birds did not vary significantly until d 42 of age. The content of total lipid in the liver in both groups increased between days 14 and 42 and then decreased on d 56 of age. During the whole experiment, the content of liver total lipid in hypodynamy quail was lower as compared to control. In both groups, liver glycogen content on d 28 was higher than that on d 14, 42 and 56 of age. Liver glycogen content in hypodynamy vs. control birds was significantly reduced on $\mathrm{d}$ 14 and increased on 42 of age.

\section{Discussion}

There are many studies that characterize the postnatal development of Japanese quail chicks under standard rearing conditions (Lilja 1982; Laskey and Edens 1985). The current study examined differences in female Japanese quail physiology due to simulated microgravity (hypodynamy). Our interest was focused on a period of post-hatching development from d 3 to 56 of age. During this period, the effects of hypodynamy on concentration of total protein, total lipid and glycogen in muscles and liver were studied. The obtained results confirmed the retarding effects of hypodynamy on the development of female Japanese quail chicks ( Š krobánek et al. 2004). It was demonstrated that the content of total protein in both examined muscle types of birds exposed to a long-term hypodynamy decreased by 1.4 to $8.5 \%$ as compared to the age-matched control. The total lipid content in samples of both muscles and liver of quail subjected to hypodynamy decreased by 8.9 to $71.2 \%$. In contrast, the content of glycogen in the examined samples of both groups was very variable. Glycogen content of experimental quail was significantly increased in both skeletal muscles on 14 and in the liver on d 42 of age. On the other hand, the biochemical indicators found in female Japanese quail of control group in the present study are in agreement with previous findings (B a mgartner 1990; Marks 1993; Yalcin et al. 1995).

What were the reasons for these differences? Firstly, although adrenal steroid levels were not measured in the present study, we speculate that quail under hypodynamy might be affected by stress in the first days after hatching that caused a decrease of food conversion and induced subsequent delays in the early growth and development of organ systems and their functions. Later on, towards the end of experiment, it is not possible to catch up with the development and to eliminate these differences during the following ontogenetic phases. Secondly, the above mentioned differences could be caused by an absence of free movement that is essential for the development of the quail organism. For example, higher glycogen content in the liver of female Japanese quail was recorded in individuals reared under hypodynamy than those of the control group on $\mathrm{d} 14$ and 42 of age. Thirdly, the reasons for differences may be based on a different direction of gravity loading on skeletal muscles of 
test quail exposed to hypodynamy as compared to control. Biochemical indicators in oneday-old chicks are a special case. The high levels of total lipid and glycogen in the muscles and liver of one-day-old quail may be explained by the presence of yolk sac residua. A considerable decline of total lipid on $\mathrm{d} 56$ to the level of $\mathrm{d} 14$ of age may be explained by the onset of egg-laying. The control quail hens began to lay eggs on $\mathrm{d} 37$ and half of these birds laid their first eggs by d 39 of age. The experimental birds laid their first eggs on $\mathrm{d} 43$ of age and 50\% of egg-laying in this group of birds was reached by $\mathrm{d} 46$.

Based on our previous observations we expected that hypodynamy would markedly affect levels of the variables under study. It was demonstrated that hypodynamy reduced the body weight, food consumption and conversion, and the size of the femur and tibiotarsus in the developing female Japanese quail chicks (Šk krobánek et al. 2004). Nevertheless, it is difficult to compare our results with those of other authors, because no similar experiments concerning quail development from hatch to maturity under conditions of hypodynamy have been carried out. The body weight of 2-3-d-old and 4-5-d-old quail chicks hatched in space was reduced by 26-30\% as compared to control birds (Dadasheva et al. 2001). In adult Japanese quail, it was reported that leg periosteal bone formation and tubular bone growth was gradually decreased during the 33-d hypodynamy (Guryeva et al. 1998). Simulated microgravity induced also morphological differences in striated musculature (Kočišo vá et al. 1998). S a bo et al. (1998) reported that adult Japanese quail under 84-days hypodynamy decreased their body weight by about $14 \%$. Similar responses were observed in the adult quail individuals after one week exposure to microgravity aboard the MIR orbital space station ( Sabo et al. 1992).

In conclusion, this report is the first study examining the effects of hypodynamy (simulated microgravity) on the growth and development of breast and thigh muscles and liver in female Japanese quail between 3 and $56 \mathrm{~d}$ of age. The obtained results indicated that hypodynamy had a significant impact on the weight, dry matter, and content of proteins, lipids and glycogen. Therefore, this data may by useful for understanding quail post-hatch development in conditions of altered gravitaty during a real space flight.

\section{Vplyv simulovanej mikrogravitácie na koncentráciu metabolitov vo svaloch a pečeni vyvíjajúcich sa kurčiat prepelice japonskej}

K štúdiu negatívnych účinkov mikrogravitácie na živočíšny organizmus sa $\mathrm{v}$ pozemských podmienkach najčastejšie používa hypodynamia. Cielom tejto práce bolo skúmat vplyv hypodynamie na rast a vývin prsného svalu, stehenných svalov a pečene kurčiat prepelice japonskej od 3 do 56 dní veku. Vzorky svalov a pečene boli získané v 1 , 14, 28, 42 a 56 dňoch, pričom hodnotené boli tieto ukazovatele: hmotnost' (g), relatívna hmotnost (\%), sušina ( $\mathrm{mg} / \mathrm{g})$ a obsah celkových proteínov, celkových lipidov a glykogénu (mg/g).

Hmotnost prsného svalu, stehenných svalov a pečene sa postupne zvyšovala s vekom zvierat u obidvoch skupín. V raste pokusných jedincov vystavených hypodynamii bola však $\mathrm{v}$ porovnaní s kontrolou pozorovaná určitá redukcia. Na konci pokusu bola priemerná hmotnosṫ tela hypodynamickej skupiny signifikantne nižšia $(P<0,05)$. Kontrolné vtáky mali v porovnaní s pokusnou skupinou taktiež tažší prsný sval. Podobne sušina a celkové lipidy v obidvoch svaloch a pečeni jedincov kontrolnej skupiny boli signifikantne vyššie $(P<0,05)$. Naopak, rozdiely v obsahu celkových proteínov a glykogénu vo svaloch a pečeni obidvoch skupín neboli na konci experimentu štatisticky významné.

Dosiahnuté výsledky poskytli d’alší dôkaz o tom, že hoci hypodynamia ovplyvňuje skúmané ukazovatele vybraných kostrových svalov a pečene, prepelica japonská samičieho pohlavia je schopná vyvíjat sa v podmienkach simulovaného beztiažového stavu. 


\section{Acknowledgements}

This work was supported by the Grant Agency for Science of Slovak Republic, VEGA grant No. 2/6024/26

\section{References}

BAUMGARTNER J 1990: Prepelica japonská ako laboratórne zviera (Japanese quail as laboratory animal). In Slovak, VEDA, vydavatelstvo Slovenskej akadémie vied, Bratislava, 98 p.

BOĎA K, SABO V, JURÁNI M, GURYEVA TS, KOČIŠOVÁ J, KOŠŤÁL L, LAUKOVÁ A, DADASHEVA OA 1992: Embryonic development and behaviour of Japanese quail exposed to microgravity. Acta Vet Brno 61: 99-107

DADASHEVA OA, GURYEVA TS, SABO V, BOĎA K, KOČIŠOVÁ J 2001: Research into morphology of Japanese quails hatched under conditions of microgravity. Folia Vet 45 (Suppl. 1): S12-S16

DREILING CE, BROWN DE, CASALE L, KELLY L 1987: Muscle glycogen: Comparison of iodine binding and enzyme digestion assay and application to meat samples. Meat Sci 20: 167-177

GURYEVA TS, DADASHEVA OA, MELESHKO GI, SHEPELEV YE YA, BOĎ K, SABOV 1993: The quail embryonic development under the conditions of weightlessness. Acta Vet Brno 62 (Suppl. 6): S25- S30

GURYEVA TS, MEDNIKOVA EI, DADASHEVA OA, POVALKO NB 1998: The musculoskeletal apparatus of Japanese quail during hypodynamy. Folia Vet 42 (Suppl.): S37-S39

HULLINGER RL 1993: Embryogenesis aboard Shuttle STS-29. Acta Vet Brno 62 (Suppl. 6): S17-S23

JURÁNI M, VÝBOH P, LAMOŠOVÁ D, BAROŠKOVÁ Ž, SOMOGYIOVÁ E, BOĎA K, GAŽO M 1983: The effect of a 90-day hypodynamy on the neurohumoral system, egg laying and metabolism of proteins in Japanese quail. Physiologist 26 (Suppl. 6): 145-148

KOČIŠOVÁ J, SABO V, TOMAJKOVÁ E, BOĎA K 1998: Morphological changes in m. gastrocnemius during hypodynamy. Folia Vet 42 (Suppl.): S41-S44

LASKEY JW, EDENS FW 1985: Hatch weight selection: effect on post-hatch growth in the Japanese quail (Coturnix coturnix japonica). Comp Biochem Physiol PT A 82: 101-104

LILJA C 1982: Postnatal growth and organ development in the quail (Coturnix coturnix japonica). Growth 46: 88-89

LOWRY OH, ROSEBROUGH NJ, FARR AL, RANDAL RJ 1951: Protein measurement with the Folin phenol reagent. J Biol Chem 193: 265- 275

MARKS HL 1993: Carcass composition, feed intake, and feed efficiency following long-term selection for fourweek body weight in Japanese quail. Poult Sci 72: 1005-1011

ORBAN JI, PIERT SJ, GURYEVA TS, HESTER PY 1999: Calcium utilization by quail embryos during activities preceding space flight and during embryogenesis in microgravity aboard the orbital space station, MIR. J Grav Physiol 6 (2): 33-41

SABO V, BODA K, GURYEVA TS, DADASHEVA OA 1992: Changes in the body and organ mass of Japanese quail after a 7-day exposure to microgravity. Acta Vet Brno 61: 109-113

SABO V, BOĎA K, GURYEVA TS, DADASHEVA OA, BELLA I 2001: The study of postembryonic development of Japanese quail chicks under microgravity and load on the orbital station MIR. Folia Vet 45 (Suppl. 1): S9-S11

SABO V, CHRAPPA V, BOĎA K 1998: Effect of long-term (84-days) hypodynamy on the efficiency of Japanese quails. Folia Vet 42 (Suppl.): S59-S61

ŠKROBÁNEK P, BARANOVSKÁ M, JURÁNI M, ŠÁRNIKOVÁ B 2005: Influence of simulated microgravity on leg bone development in Japanese quail chicks. Acta Vet Brno 74: 475-481

ŠKROBÁNEK P, HRBATÁ M, BARANOVSKÁ M, JURANI M 2004: Growth of Japanese quail chicks in simulated weightlessness. Acta Vet Brno 73: 157-164

ŠKROBÁNEK P, SABO V, BOĎA K, BARANOVSKÁ M, MRAVCOVÁ I 2001: The capacity of Japanese quail hatchlings to adapt to hypodynamy. Folia Vet 45 (Suppl. 1): S69-S70

YALCIN S, OGUZ I, OTLES S 1995: Carcase characteristics of quail (Coturnix coturnix japonica) slaughtered at different ages. Poult Sci 36: 393-399 